\title{
DEPORTATIONS FROM POLAND AND THE BALTIC STATES TO THE USSR IN 1939-1941: COMMON FEATURES AND SPECIFIC TRAITS
}

\author{
NATALIIA LEBEDEVA
}

ABSTRACT The aim of this article is to compare repression policies of the Stalinist regime on the territories annexed by the Soviet Union in September 1939 and June-August 1940. The planning and implementation of deportations from the west of Ukraine and Belorussia, Lithuania, Latvia and Estonia had much in common. All the deportations were prepared and carried out on the basis of decisions carefully worked out by the Politburo of the Central Committee of the All-Union Communist (Bolshevik) Party and was an important element of the sovietization policy on these territories. Deportation was a part of measures designed to destroy political, judicial, social, economic, national, cultural and moral fundamentals and to impose the Soviet order in the annexed territories. Methods of their organization and implementation were absolutely identical. All these deportations were crimes against humanity.

At the same time there were certain differences. The planned capture of armies did not take place at the time of the Soviet invasion of the Baltic states. There were no such mass shootings of officers, policemen and jail inmates as in case of Poland. The scale of deportation was not as large as on territories of eastern Poland. This could be explained by the fact that the peoples of the Baltic states considered Sovietization as national humiliation to much larger extent than the peoples who had suffered under Polish or Romanian yoke. It forced the Stalinist ruling elite of the USSR at first to demonstrate a certain respect towards local customs, carry out nationalization of industry and banking slowly and more cautiously, to refrain from collectivization and not carry out mass deportation until the very eve of war between the Soviet Union and Hitler's Germany.

The deportation of a certain part of the Polish, Latvian, Lithuanian and Estonian population from the territories annexed by the Soviet Union in September 1939 and August 1940 was carried out in the framework of Stalin's policy of destroying the state systems of Poland and the Baltic States. Sovietization of Lithuania, Latvia, 
Estonia and western regions of Ukraine and Belorussia then followed.

A fresh look at the problem became possible following easier access to some archives including those of the Central Committee of the Soviet Communist Party, the Council of People's Commissars, NKVD and its POW Agency.

The aim of this article is to compare repression policies followed by Stalin's regime at the time when these annexed territories were sovietized.

Vigorous political and military preparations for the incorporation of the eastern Polish territories and the Baltic States into the USSR were carried out in accordance with resolutions adopted by the Communist Party Politburo.

On 9 September 1939 K. Voroshilov, the Defence Commissar, and B. Shaposhnikov, Head of General Staff, signed an order instructing the Soviet troops to cross the Soviet-Polish border on the night of 13 September that year. ${ }^{1}$ However, the news that Warsaw was still holding out seems to have caused the Soviet leaders to postpone the invasion until the dawn of 17 September.

On 8 September L. P. Beria ordered special chekist groups to be formed in each of the nine armies comprising the Ukrainian and Belorussian 'Fronts. They were given the task of seizing prisons, post offices, banks and presses. Also, they had to set up provisional authorities, detain prominent statesmen, the leaders of political parties and so on. Having entered the Polish territory together with Red Army regular units on 17 September 1939, Beria's men carried out mass arrests of the ruling elite's representatives. For instance, one group of the nine alone had arrested 1923 persons by 28 September. $^{2}$

On 1 October the Politburo adopted a programme of sovietization of the occupied territories which was to become a pattern for the sovietization of the Baltic republics. After the 'reunification" of Ukraine and Belorussia with their corresponding western parts, formally implemented on 1-2 November, their total

${ }^{1}$ Katyn'. Plenniki neob 'iavlennoi voiny. Dokumenty, ed. N. S. Lebedeva, R. G. Pikhoia and A. Geishtor (Moscow, 1997), pp. 59-63.

${ }^{2}$ Organy gosudarstvennoi bezopasnosti SSSR v Velikoi Otechestvennoi voine. Sbornik dokumentov, Vol 1. Nakanune. Book 1. (Moscow, 1995), pp. 70-73, 79-81, 96-97. 
administrative, economic, financial, social and ideological unification with the Soviet Union became the key task of the Stalinist establishment which at the same time did its best to isolate those who opposed the process. ${ }^{3}$

By the end of September more than 240,000 Polish servicemen had been taken prisoner by the Red Army, 124,000 of them transported to the USSR. However, the NKVD POW camps were unfit to accommodate and feed them and on 3 October the Politburo made a decision to free 42,400 ordinary soldiers and junior ranks of the former Polish Army, who previously lived on the annexed territory. Soon an agreement between the USSR and Germany had been reached to exchange the Polish POWs. The Soviet Union received 13,757 and turned over 42,492 noncommissioned officers and soldiers. At the same time the Politburo assigned 25,000 captured Polish military men for construction works on the Novograd-Volynsk-Lvov highway. Shortly afterwards some of them were transferred to mines in the Krivoi Rog and Donets basins. Subsequently, by 1 November 1939 three special camps had been founded, including two for 8,500 officers in Kozelsk and Starobelsk and one in Ostashkov for 6,500 policemen, gendarmes and border guards. Four labour camps were set up for 25,000 POWs. ${ }^{4}$

In addition, 108,000 citizens had been arrested in western regions of Ukraine and Belorussia in the period between September 1939 and June 1941.

The deportation of Poles was the most substantial. It was done in four major waves and involved more than 320,000 persons. This was accompanied with a number of other measures the Soviet leadership took to sovietize the annexed territory.

On 3 December 1939 the Politburo decided to arrest all registered officers of the former Polish Army. It resulted in 1,057 officers being arrested in one week between 3 and 10 December.

On 4 December a decision was made to assign 30,000 refugees to forced labour. Ten thousand were sent to the construction industry,

${ }^{3}$ Rossiiskii Gosudarstvennyi Arkhiv Sotsialno-Politicheskoi Istorii (RGASPI), f 17, op. 3, d. 1014, ff. 57-72.

${ }^{4}$ N. S. Lebedeva, Katyn': prestuplenie protiv chelovechestva (Moscow, 1994), pp. $42-134$.

5 O. A. Gorlanov, A. B. Roginskii, 'Ob arestakh v zapadnykh oblastiakh Belorussii i Ukrainy', Istoricheskie sborniki 'Memoriala', fascicle 1. Repressii protiv poliakov i polskikh grazhdan (Moscow, 1997), pp. 77-113. 
10,000 to the Forestry Commissariat enterprises, 6,000 to collective farms and 7,000 to other industries. ${ }^{6}$

On 5 December the Politburo adopted a resolution to organize the first deportation of Poles to the Soviet Far North and Siberia. This comprised 21,000 families of osadniks - Polish military colonists, army veterans who received land plots in the provinces which had been incorporated into Poland in 1921 by the Treaty of Riga. The directives of the Soviet Communist Party stipulated that special settlements for 100-150 families each were to be founded for these unfortunates. The adult population was to work in woodcutting and had no right to leave their dwellings for more than 24 hours. The resettlement had to be carried out at the beginning of February 1940, in the dead of winter. ${ }^{7}$

On 21 December the Politburo approved the proposal put forward by the Ukrainian and Belorussian Communist Parties on the disposal of property belonging to the military colonists. Their land, horses, cattle, agricultural machinery and tools were to be divided among state and collective farms. Their houses had to be handed over for use by schools, hospitals, soviets, collective farm management bodies and as quarters for teachers and doctors. Included in the deportees were also the so-called 'foresters' ${ }^{\text {- }}$ members of special detachments who were guarding woods. In this way, the aim of the forced deportations was not only to remove the most active part of the Polish population who were trained in the use of arms from the west of Ukraine and Belorussia but also to create a material base for the sovietization and collectivization of these regions. ${ }^{8}$

On 29 December the Politburo decided 'to approve the NKVD proposal concerning military colonists which had been drafted by Comrade Vyshinskii'. Attached to the order was an instruction issued by Beria and 'Regulations on Special Settlers' which provided for the resettlement to be carried out simultaneously in the Ukrainian and Belorussian republics on the day specified by the NKVD. All the property of the military colonists was to be put at the disposal of local authorities. The resettlers were allowed to take with them only their clothes, linen, footwear, bedding, tableware, cooking utensils, pails, hardware, money, jewellery, suitcases and food for

${ }^{6}$ RGASPI, f. 3, op. 162, d. 26, ff. 155-157.

${ }^{7}$ Ibid., ff. 120, 152-154.

${ }^{8}$ Ibid., ff. $155-157$. 
a month. In addition, the total weight of such items was not to exceed 500 kilograms per family. ${ }^{9}$

On 14 December 1940 the Council of People's Commissars and the Central Committee of the Communist Party issued a joint resolution 'On the Supplementary Distribution of Military Colonists'. This provided for an increase in the number of exiled families by 5,000 and indicated that their forced labour would include mining as well as working at undertakings of the Precious Metals Commissariat. ${ }^{10}$

According to these decisions on 10 February 1940 the NKVD had deported 139,590 Polish citizens. They were distributed throughout 21 oblasts (districts) and krais (territories) and settled in 115 villages. The largest number of deported families was sent to the districts (oblasts) of Arkhangelsk (8084), Irkutsk (3114), Sverdlovsk (2809), Krasnoyarsk Krai (3279) and Komi Autonomous Republic (2191). In all, 28,612 families were resettled in this campaign. ${ }^{11}$

The deportation was carried out in a single day in accordance with a list prepared by the NKVD in advance. Each operational group was led by a team comprising three men. The routes to reception points were designated in advance and operational groups were assembled on the eve of deportations. No one was permitted to leave the headquarters even for a minute. The leader of an operational group examined the composition of each of two or three families entrusted to him, approaches to the house and intelligence reports on military colonists. The operation was to begin at dawn in order to avoid 'unnecessary clamour and panic'. Railway stations were to be surrounded by escort troops.

People were transported in badly heated carriages with temperatures hitting minus 25-30 degrees centigrade. They began to die en route. No preparations were made to receive the deportees. Quite often people could not find any shelter and/or food upon their arrival. All this contributed to the high death rate. Out of total of 139,500 deportees there were only 33,000 men above 18 years of age. By August 1941 only 131,938 were still alive. $^{12}$

9 Ibid., ff. 159, 187-190.

${ }^{10}$ Gosudarstvennii arkhiv Rossiiskoi Federatsii (GARF), f. 5446, op. 57, d. 78 . ff. 1,12 .

${ }^{11}$ Ibid., f. 9479 , op. 1 , d. 61 , fo. 120 ; f. 9459 , op. 57 , d. 65 , ff. 34-36.

12 Ibid., f. 9479 , op. 57 , d. 65 , ff. 36-39; op. 1c, d. 62 , fo. 67. 
On 2 March 1940 the Politburo decided 'to strengthen security in the border region" and 22,000-25,000 family members of captured Polish officers and policemen along with inmates of Polish jails on the annexed territory were deported to Kazakhstan for a term of ten years. ${ }^{13}$

On 5 March it was decided to shoot 14,700 POW-officers and policemen together with 11,000 prisoners in jails in the west of Ukraine and Belorussia. ${ }^{14}$ Immediately after the decision had been made intensive preparations began for carrying out the execution of the POWs and deporting their families. Beria ordered lists of family members and their location to be compiled on the basis of special questionnaires given out to captured officers and policemen. On 7 March Beria sent to interior commissars of Ukraine and Belorussia, I. A. Serov and L. F. Tsanava respectively, an order on the deportation of families of the officers, policemen, officials, landowners and industrialists who were kept in POW camps and jails on annexed territory. ${ }^{15}$

In accordance with the Politburo decision of 5 March 1940, 15,131 officers and policemen along with 7,305 jail inmates were shot in the period from April to May, while on 13 April their families $\left(66,000\right.$ persons) were sent to Kazakhstan. ${ }^{16}$

On 29 June another large-scale deportation took place when 76,382 persons (25,682 families) were scattered among 14 different regions and republics of the USSR. ${ }^{17}$ These were mainly people who had fled from central Poland, i.e. refugees saving their lives and escaping from Germans!

The last mass resettlement of non-combatant Poles, Ukrainians and Belorussians amounting to $36,000-40,000$ persons was carried out simultaneously with deportations from the Baltic states and Moldavia on the eve of the German-Soviet war. This was initiated by Ukrainian State Security Commissar P. Y. Meshik on 15 April 1941 when he approached Ukraine's party boss, N. S. Khrushchev,

${ }^{13}$ Katyn', pp. 375-378.

14 Ibid., pp. 384-392.

15 Ibid., pp. 523-524.

${ }^{16}$ N. S. Lebedeva, 'The Deportation of the Polish Population to the USSR, 1939-1941', Forced Migration in Central and Eastern Europe 1939-1950, ed. A. J. Rieber (London, 2000), pp. 28-45.

${ }^{17}$ Rossiiskii Gosudarstvennyi Voennyi Arkhiv (RGVA), f. 40, op. 1, d. 70, ff. 14, 28-29; GARF, f. 9479, op. 1, d. 1, fo. 47. 
with a proposal to fight the Organization of Ukrainian Nationalists (OUN) more vigorously. To this end he asked to set before the Soviet Communist Party Central Committee and Council of People's Commissars the issue of applying the state treason law to all members of the underground active in western Ukraine as well as to their families and the families of arrested OUN members and kulaks. It was suggested that all of them be deported to remote areas of the USSR. ${ }^{18}$ On 24 April State Security Commissar V. N. Merkulov signed the instructions regulating the resettlement order for all family members of the persons who were hiding underground and persons sentenced for taking part in counterrevolutionary organizations of Ukrainian, Belorussian and Polish nationalists. They were to be deported to remote regions of the USSR for terms of between 5 and 8 years. ${ }^{19}$

On 14 May 1941 the Politburo approved the resolution adopted by the Central Committee of the Communist Party and the Council of People's Commissars, decreeing measures:

To oblige the Ukrainian Commissariats of Interior and State Security to go on removing the members of counter-revolutionary OUN organizations. To arrest and send to exile for 20 (!) years with the confiscation of their property: a) family members of persons participating in Ukrainian and Polish counter-revolutionary nationalist organizations in cases when the heads of such families are hiding underground from power bodies; b) family members of persons participating in the above organizations in cases where the heads of such families have been condemned to death.

The Soviet Interior and State Security Commissariats along with the Belorussian Communist Party boss, Ponomarenko, were commissioned 'to take similar measures in respect to western Belorussia'. ${ }^{20}$ The operation to deport the families of repressed persons and those hiding underground was carried out in Western Ukraine on 22 May and on the night of 20 June in Belorussia. 11,329 persons were deported from Ukraine and more than 21,000 from Belorussia. ${ }^{21}$

${ }^{18}$ Organy, I:2, pp. 147-148.

${ }^{19}$ GARF, f. 9401, op. 2, d. 1, ff. 284-288.

20 Arkhiv Presidenta Rossiiskoi Federatsii, f. 93. The Collection of Resolutions.

21 Organy, I:2, pp. 154-155; A. E. Gur'ianov, 'Masshtaby deportatsii naseleniia v glub' SSSR v mae-iiune 1941 g.', Istoricheskie sborniki 'Memoriala', fasc. 1, pp. 156-158. 
The aim of all these deportations, apart from unhindered dePolonization and sovietization of territory that had been incorporated into the Soviet Union, was to provide newly-founded collective and state farms with necessary material resources. They were given land, buildings, cattle, machinery, etc. The confiscated houses and apartments were used as living quarters for Soviet state and party officials, Red Army commanders, doctors and teachers.

The forced incorporation of the Baltic states into the USSR differed from the annexation of eastern Polish regions. It was conceived and carried out as a multi-step combination. The fact that the Third Reich had recognized Lithuania, Latvia and Estonia as being within the Soviet sphere of interests in Europe allowed Stalin to impose 'mutual assistance agreements' upon these countries and locate Red Army units on their territory. Thus, an instrument of influence was created in the Baltic region. Great Britain and France were inclined to consider it a lesser evil in comparison with a possible German occupation. The defeat of France and withdrawal of the British Expeditionary Force from the Continent opened the doors for the annexation.

Harsh diplomatic pressure which began in May 1940 and was accompanied with invasion threats (serious measures were taken in this respect ${ }^{22}$ ) had set a hard choice before the Baltic governments: fight or surrender. Being isolated in international terms, they saw clearly the vanity of resistance and being unable to alter matters they accepted the Kremlin's conditions. On 15 June the Soviet Eighth Army invaded Lithuania and on 17 June Latvia and Estonia were also taken over. Thus the process of forced incorporation of the Baltic states into the USSR, which ended at the beginning of August 1940, began.

Already in first part of June essential measures were taken not only to invade the countries but also to capture and deport a greater part of their military and policemen deep into the Soviet Union. Ten reception points for 5,000 persons each had been set up on the borders. The NKVD POW Agency commissar S. V. Nekhoroshev himself went to Grodno to become a camp commandant. Former POW camp commandants in the Krivoi Rog basin Reviakin, Vtorov, Vasiliev and Kabanov went to the towns of Ostrov, Sony, Kingisepp

${ }^{22}$ M. I. Mel'tiukhov, 'Narashchivanie sovetskogo voennogo prisutstviia v Pribaltike v 1939-1941 godakh', Novaia i noveishaia istoriia, 4, 1999, pp. 46-70. 
and Pskov, while the gulag employees Svechnikov and Filin came to Svonuchiny and Sebezh. The POW Agency inspector Bunakov left for Bigosovo. The POW Agency Deputy Chief I. I. Khokhlov who was a key figure in shooting the Polish officers and policemen in April-May 1940 had to head all the work connected with the reception of POWs. ${ }^{23}$

The matter of guarding the reception points (camps) and escorting trains to their final destination had been also worked out in detail. On 9 June V. V. Chernyshev reported to his superiors that escort troops were ready to guard the following camps: Ostashkov (for 8,000 men); Kozelsk, Starobelsk, Iukhnov, Oransk (for 5,000 men each); Karaganda (4,000); Temnikovo (2,000) and the Belomoro-Baltiisk camp for 20,000 men, i.e. 56,000 in all. A few days later the POW Agency Chief P. K. Soprunenko presented a reference note where a higher number appeared: 9,000 for Ostashkov, 8,500 each for Kozelsk, Starobelsk and Iukhnov, 6,000 for Karaganda and Putivl, 3,000 - Oransk and Temnikovo, 2,000 at Velikii Ustiug, while other gulag camps held 8,000, i.e. 64,000 POWs in total ${ }^{24}$, while the combined strength of all three Baltic Armies amounted to a little more than 70,000 men.

All the camps were warned about the new forthcoming contingent. Additional guards were sent there, including NKVD schools' cadets. The question concerning the coming of POWs from the Baltic states was still in force after 'additional' Red Army formations entered there and full control over the region had been established. On 17 June 1940 Defence Commissar S. K. Timoshenko sent a memo to Stalin and Molotov where, among other things, he wrote that they should:

3. solve the problem with 'the government' of occupied republics as soon as possible. 4. begin the disarmament and disbanding of the occupied republics' armies. To disarm the population, police and existing militarized organizations. 5. charge our troops with garrisoning and guarding the objects. 6 . begin sovietization of the occupied regions resolutely. 7. set up a Baltic Military District on the territory of occupied republics... ${ }^{25}$

The latter was created in accordance with a Politburo decision of 10 July. The Baltic Armies were incorporated into the

${ }^{23}$ RGVA, f. 1/p, op. 3a, d. 1, ff. 33-34.

${ }^{24}$ Ibid., d. 3, fo. 30; d. 1, fo. 67.

${ }^{25}$ RGVA, f. 4, op. 19, d. 71, ff. 238-138ob.; Mel'tiukhov, 'Narashchivanie', p. 65. 
Red Army as independent territorial corps in accordance with a Politburo resolution of 14 August and Defence Commissar's order of 17 August. At the beginning of July the reinforced guarding of the camps which were to receive Baltic POWs was removed. ${ }^{26}$

Having abandoned its initial plans to deport the Baltic servicemen to remote regions of the USSR, the NKVD was fast to capture the Poles who had been interned in Lithuania and Latvia since 1939 and dispatch them to the Soviet Union. By Beria's order of 6 July 1940, 4,676 persons, including 2,357 officers and policemen, were soon sent to Kozelsk and Iukhnov camps from Lithuania. Since they were scattered across the whole territory local authorities were instructed to re-register the interned persons and detain all who were coming. 811 more Poles were brought to Kozelsk and Iukhnov from Latvia at the beginning of September. Some of them were transferred to central, republican and regional bodies of the NKVD and vanished without trace. In September 1941 most of the Poles were transferred to form a Polish Army on the Soviet territory (General Anders' Army). ${ }^{27}$

The idea of detaining and deporting Lithuanian, Latvian and Estonian servicemen was revived only in spring 1941 and was put into effect on the night of 13-14 June 1941. Nevertheless, in the initial sovietization period many commanders and officers of the three annexed countries had been already arrested and deported. On 19 July 1940 the Chief Commander of the Estonian Army, I. Laidoner, was arrested at his estate and deported to the USSR together with his spouse. ${ }^{28}$ At the same time 25 out of 28 generals, both in active service and retired, as well as many other Estonian officers who refused to serve with the Soviet power or were not adopted by special commissions of the Baltic Military District, were deported.

Even before the formal incorporation of the Baltic states into the USSR the NKVD emissaries began arresting the army and police officers, leading political and public figures. Thus on 22 July 1940 in accordance with the order issued by A. J. Vyshinskii, the Latvian President K. Ulmanis had been taken from Riga Castle (his official residence) and brought to the USSR where he died in prison in 1942. Foreign Minister V. Munters and many other Cabinet

${ }^{26}$ RGASPI, f. 17, op. 3, d. 1025, fo. 39; RGVA, d 1/p, op. 3a, d. 3, ff. 5, 13.

${ }^{27}$ See Lebedeva, Katyn', pp. 249-266.

${ }^{28}$ M. Raud, Riigiehitaja Konstantin Päts (Stockholm, 1977), pp. 158-159. 
members were also arrested there and later deported. On 30 July Vyshinskii telegraphed to Molotov:

Let me inform you about the questions we discussed yesterday. I consider it necessary to send the following persons out of Latvia to the USSR: 1) General Balodis; 2) former Interior Minister Wiednek; 3) former Defence Minister Berkis. As to the former Minister of Public Works Beznis, it can be said that according to the information available at present he is hiding somewhere and we are looking for him. ${ }^{29}$

On 30 July the President of Estonia, K. Päts, and members of his family, who had American entry visas, were arrested and deported to the USSR. Nine out of eleven Cabinet ministers were also arrested along with 50 out of 60 former government members and 250 out of 308 active and former members of Parliament. Twenty two Lutheran pastors were deported and two killed. Two out of five Catholic priests were deported as well ten Orthodox priests, while three were killed. ${ }^{30}$

The scale of repressions became much larger after the incorporation of the three republics into the USSR. Arrests and deportations were often connected with nationalization of property and land reform. For example, the Soviet representative in Estonia, V. Bochkarev, asked the Communist Party Central Committee's secretary, A. A. Andreev, to deport from the country the landowners whose land had been confiscated. Special commissions had been set up with republican party committees at the beginning of October 1940. In ten days they were to compile the lists of 'landowner/enslavers' to be deported and work out the order of using the property confiscated from them. In particular, the Lithuanian Communist Party Committee decided to ask Moscow for a permission to deport all 'the landowner/enslavers' from the republic. The local NKVD was instructed in five days to define the lists of such people more accurately and submit them for confirmation to the Central Committee of the Lithuanian Communist Party. This resulted in compiling reference notes on deportation of 587 landowners, which accordingly were sent to Moscow. ${ }^{31}$

${ }^{29}$ RGASPI, f. 82 , op. 2, d. 150 , fo. 14.

${ }^{30}$ Na chashe vesov: Estoniia i SSSR. 1940 i ego posledstviia, ed. P. Vares, O. Zhur'iari (Tallinn, 1999), pp. 419-420.

${ }^{31}$ RGASPI, f. 17 , op. 121, d. 52, ff. 25-29; d. 73, ff. 62-64. 
On 6 November 1940 the Soviet Supreme Council approved a decree concerning the application of criminal, civil and labour laws of the Russian Federation on the territory of the Lithuanian, Latvian and Estonian Soviet Socialist Republics. The laws were to be applied also in regard to acts committed before the incorporation of these states into the USSR. ${ }^{32}$

Since the beginning of 1941 the Politburo punishment policy became more severe. Secretary A. A. Andreev had been sent to the region to supervise operations. On 12 January he wrote to Stalin and Molotov:

Unlike Latvia and Estonia, Lithuania has many Catholic monasteries, Polish Roman Catholic churches, Jesuit and Franciscan orders. Numerous clergy are doing anti-Soviet work openly among the population, preparing to frustrate the elections [to the Supreme Council of the USSR]. At the same time our ruling bodies in Lithuania together with the Lithuanian NKVD rebuff impudent Catholics rather timidly.

In his turn, Zhdanov stressed: ' ... the Latvian people will be ruthless in respect to those who have not laid down their weapons'. ${ }^{33}$

The departure of the German population from the Baltic states to their home country which was planned to be finished on 25 March contributed to the sovietization process. By 14 March 3,773 families had left Lithuania, 163 left Estonia and 163 had gone from Latvia. $^{34}$

In February the passport system was introduced and guarding of borders strengthened. In this connection the republican central committees of Communist parties decided to resettle from 'towns of the first rank' and regions adjoining the state border former bankers, industrialists, landowners, kulaks, merchants, government members, aristocrats, political police officers, officials of ministries and departments, leaders of nationalist, fascist and government parties, organizations and groups, along with criminals and prostitutes. ${ }^{35}$

The central machinery of the NKVD and NKGB worked out the regulations on a resettlement of these citizens by 24 April

${ }^{32}$ M. I. Semiriaga, Tainy stalinskoi diplomatii 1939-1941 (Moscow, 1992), p. 247.

${ }^{33}$ RGASPI, f. 17 , op. 121 , d. 70 , ff. 4-6; d. 75 , fo. 6 .

34 Ibid., d. 60, ff. 6-7.

${ }^{35}$ RGASPI, f. 17, op. 22, d. 1664, ff. 119-120. 
1941. Actually, the document repeated the order of mass deportation of Poles from the western regions of Ukraine and Belorussia. ${ }^{36}$

According to these instructions, shortly before the German onslaught deportations were carried out in Western Ukraine (22 May), Moldavia (13 June), Lithuania, Latvia and Estonia (14 June), Western Belorussia (20 June).

In contrast to the three mass deportations from the Western Ukrainian and Belorussian regions this operation was not carried out simultaneously and involved not only the Poles but also nationalist-minded Ukrainians, Belorussians, Latvians, Estonians, Lithuanians, Moldavians, etc. All the areas annexed by the USSR in the period from 1939 to 1940 became the deportation zone. Although the numbers of the last pre-war deportation were smaller than during the February resettlement of military colonists and foresters in 1940 it was conceived as a significantly more complicated operation than previous ones. It differed mainly in the way it distinguished the legal status of the repressed people. In the three mass deportations of 1940 their status was the same. The military colonists and foresters of the February wave and refugees of June were considered as special settlers and placed in isolated NKVD settlements. They were obliged to work in timber cutting, mining, etc. The families of POWs and jail inmates shot in April and May 1940, who had been deported to Kazakhstan, were considered as exiled in an administrative order. They were located in settlements and collective farms that already existed, sometimes in towns, and were provided with neither work nor housing.

The categories of those exiled in June 1941, and above all of those who were deported from the Baltic republics and Moldavia were more varied. It was reflected in 'The Directive of the NKVD of the USSR on Deportation of Socially-Alien Elements from the Baltic Republics, Western Ukraine, Western Belorussia and Moldavia' as well as in 'The Information Concerning the Number of Registered Anti-Soviet and Socially-Alien Elements Based on the Data of State Security Commissariats of Lithuanian, Latvian and Estonian Soviet Socialist Republics'. 37

${ }^{36}$ GARF, d. 9401 , op. 2, d. 1, ff. 284-288.

${ }^{37}$ GARF, f. 9479, op. 1, d. 87, ff. 37-41, 189; N. F. Bugai, 'Vyselenie proizvesti po prikazu tov. Berii...', Revista de istorie a Moldovie, 1991: 1(15). pp. 45-52; Gur'ianov, 'Masshtaby', pp. 138-139. 
On 16 May the State Security People's Commissar of the USSR, V. N. Merkulov, proposed the Politburo approve the Communist Party and Soviet Government's draft resolution to arrest and send to labour camps for the period from five to eight years with a subsequent exile for twenty years: 1) former active members of 'counter-revolutionary' parties and White Guard organizations; 2) former gendarmes and policemen; 3) prison inmates, landowners, industrialists, former leading officials; 4) former officers of Polish, Lithuanian, Latvian, Estonian and White armies; 5) criminal elements. It was suggested to deport the families of such people to remote regions of the USSR for the period of twenty years. The same fate was in store for the families of people who were hiding underground or had been shot. Cases of those exiled were to be examined by a special NKVD council after their deportation to Siberia and Northern Kazakhstan and cases of family heads after their imprisonment. Respective regulations had been adopted on 19 May, and Merkulov accordingly sent instructions to republican security organs to 'purge' the territory from anti-Soviet, socially dangerous and criminal elements. ${ }^{38}$

In accordance with 'planned measures to transport, resettle and provide with work the special contingents deported from Lithuanian, Latvian, Estonian and Moldavian Soviet Socialist Republics' persons of categories 1 to 4, persons who had been repatriated from Germany, and Germans who refused to leave for Germany were sent to POW camps (Kozelsk, Putivl), Starobelsk and Iukhnov). Their family members as well as refugees from Poland and prostitutes were to be exiled for twenty years as special settlers to Kazakhstan, the Komi Republic, the Altai and Krasnoyarsk territories, and the regions of Kirov, Omsk and Novosibirsk. Criminals were to be dispatched directly to Gulag labour camps and their cases were to be examined later by the NKVD Special Advisory Board. ${ }^{39}$ This way, three sorts of repressions were stipulated for the above categories - detention in POW camps, exile under supervision and detention in labour camps. All those repressed had one thing in common: not one of them had been formally convicted. It is worth noting that all these three categories of the repressed were typical only of the Baltic republics.

${ }^{38}$ Organy, I:2, pp. 144-150.

${ }^{39}$ GARF, f. 9479 , op. 1, d. 87, ff. 37-41. 
From Moldavia family heads were sent to POW camps and family members to exile; families from Western Ukraine and Belorussia lost members, including heads of families. For the most part, the anti-Soviet and nationalist elements arrested there were imprisoned in jails there but not sent to POW camps as it was done with persons of categories one to four in the Baltic republics and Moldavia.

Since the composition of categories who were deported and sent to camps was different the order of carrying out the operation in 1941 was different too. The instructions given to guarding troops varied according to region. In the west of Ukraine and Belorussia some family heads were not separated from their relatives and either the 'Regulations for Chiefs of Trains on Escorting Resettled Military Colonists', or the amended regulations of 5 June, were followed. ${ }^{40}$

Two other kinds of regulations had been prepared for chiefs of trains carrying their live cargo from the Baltic republics. They stipulated the separation of family heads from their families at a concentration station. At that, Group A (those who were sent to POW camps) and Group B (exiled) were placed in separate trains. Jelgava and Dvinsk (Daugavpils) were the concentration railway stations for Latvia. ${ }^{41}$ Thirty deported persons were to be placed in each carriage and they could take only $100 \mathrm{~kg}$ of luggage per family instead of $500 \mathrm{~kg}$, as had been the case with Poles in 1940.

On 17 June 1941 Merkulov sent to the Central Committee of the Communist Party his report on the deportation from the three Baltic Republics which had happened on 14 June. According to this, 5,664 persons had been arrested in Lithuania and 10,187 deported, 5,625 and 9,546 in Latvia, 5,178 and 5,978 in Estonia. In all three countries the number of those arrested and deported were 14,467 and 25,711 respectively and this included 643 officers who retired from Baltic armies at the moment of their incorporation into the Red Army, 933 officers who remained in service, 1,603 former policemen and gendarmes. ${ }^{42}$ The arrested men were immediately

${ }^{40}$ RGVA, f. 40, op. 1, d. 182, ff. 26-30; d. 184, ff. 49-52.

${ }^{41}$ RGVA, f. 18444, op. 2, d. 264, f. 156; 141-142; Gur'ianov, 'Masshtaby', pp. 141-142.

42 Organy, I:2, pp. 247-248. 
sent to POW camps in Starobelsk, Iukhnov and Putivl, from which all Polish POWs and refugees had been taken out in advance.

The people deported from Latvia had been sent to the Krasnoyarsk District and the Novosibirsk Region of Russia as well as the Karaganda Region of Kazakhstan. The POW camps received 5,921 persons and 10,396 arrived to their places of exile. ${ }^{43}$ It may be thought that some of them for some reasons could not be deported on 14 June and were added later. Merkulov mentioned this in his report of 17 June.

After the German attack upon the USSR these people were sent to the gulags. The exiled were dispatched to their designated locations while the majority of POWs were re-addressed to gulag camps on their way to Siberia. As a result, a large part of more than 40,000 repressed Baltic citizens were condemned to perish from starvation and hard work.

Nevertheless, this inhuman action failed to 'appease' the population of the Baltic states on the eve of war between the Soviet Union and Germany. Moreover, it embittered the people and made many of them take up arms and fight the Red Army troops.

Historians of the three Baltic states estimate that in the years of 1940 and 1941124,467 persons had been executed, deported and forced to migrate to Russia, 55,732 being from Estonia, 32,250 from Latvia and 30,485 from Lithuania. ${ }^{44}$

This way the planning and implementation of deportations from the west of Ukraine and Belorussia, Lithuania, Latvia and Estonia incorporated into the USSR by force had much in common. All the deportations were prepared and carried out on the basis of decisions carefully worked out by the Soviet Politburo and were an important element of the sovietization policy on these territories. The deportations were a part of measures aimed to destroy state, judicial, social, economic, national, cultural and moral fundamentals and violently spread the Soviet order on the annexed territories. Methods of their organization and implementation were absolutely identical. All cases of deportation were a crime against humanity.

At the same time there were certain differences. No military operation was carried out and the planned capture of armies did not happen at the time of the Soviet invasion of the Baltic states. Accordingly there was no need to transport tens of thousands of

${ }^{43}$ Gur'ianov, 'Masshtaby', pp. 152-153.

${ }^{44}$ The Baltic States. 1940-1972 (Stockholm, 1972), p. 53. 
POWs to Russia's remote regions as it was done with remnants of the Polish Army. Also, there were no such mass shootings of officers, policemen and jail inmates as in the Polish case. The scale of deportations themselves and numbers of exiled were not as high as on the territories of eastern Poland. This could be explained by the fact that in the course of de-Polonization of captured lands the Soviet Government counted upon a collaboration or, at least, passive attitude on the part of the Ukrainian and Belorussian population whose status was far from equal in Poland between 1918 and 1939. The peoples of the Baltic states which had enjoyed national sovereignty before their incorporation into the USSR considered sovietization as a national humiliation to a larger extent than the peoples who suffered under the Polish or Rumanian yoke. It forced the Stalinist ruling elite of the USSR at first to demonstrate a certain respect towards their local customs and traditions, to carry nationalization of industry and banking out slowly and more cautiously (introduction of Soviet currency and unified prices was postponed several times), to refrain from collectivization and not to carry out mass deportations until the very eve of war between the Soviet Union and Germany.

\section{Author Details:}

Nataliia Sergeevna Lebedeva is head of the Publication Centre of TwentiethCentury History Documents of the Institute of Universal History, Russian Academy of Sciences.

Address: Pr. Lenina 32A

117334 Moscow, Russia

\section{9-1941 M. TRE்MIMAI IŠ LENKIJOS BEI BALTIJOS VALSTYBIŲ I SSRS: BENDRIEJI BRUOŽAI IR SKIRTUMAI}

\section{Santrauka}

\section{NATALIJA LEBEDEVA}

Šio straipsnio tikslas - palyginti Stalino režimo represinès politikos raidą SSRS 1939 m. rugsėjo mėn. bei 1940 m. birželio-rugpjūčio mèn. aneksuotose teritorijose. Deportaciju iš Vakarų Ukrainos, Vakaru Baltarusijos, Lietuvos, Latvijos bei Estijos planavime bei igyvendinime pastebima daug bendrumu. Visos deportacijos buvo parengtos bei atliktos pagal Visasajunginès Komunistų (bolševikų) partijos CK politbiuro kruopščiai apgalvotus nurodymus. Trèmimai buvo šių teritorijų sovietizaci- 
jos politikos dalis, viena iš priemonių sunaikinti politinius, juridinius, ekonominius, tautinius, kultūrinius bei moralinius visuomenès pagrindus. Taip tose teritorijose ketinta įvesti sovietinę tvarką. Atskirose buvusiose nepriklausomose valstybėse trèmimų organizavimo bei iggyvendinimo būdai buvo visiškai vienodi. Visos deportacijos buvo nusikaltimas žmogiškumui.

Šiame procese būta ir tam tikrų skirtumų. SSRS jègoms užèmus Baltijos valstybes, neịvyko planuotas karinių struktūrų užgrobimas. Kitaip nei Lenkijoje, Baltijos valstybėse nebuvo taip masiškai naikinami karininkai, policininkai bei kaliniai. Deportacijos raida nebuvo tokia intensyvi, kaip Lenkijos rytinėse teritorijose - galbūt dèl to, kad Baltijos valstybiu piliečiai, kitaip nei lenkai, sovietizaciją prièmé labiau kaip tautos pažeminimą. Bent pradžioje tai verte SSRS stalinistinį elitą rodyti tam tikrą pagarbą vietiniams papročiams, lèčiau bei atsargiau nacionalizuoti pramonę ir bankus, neivvesti kolektyvizacijos bei masiškai netremti gyventojų i rytus iki pat SSRS karo su Hitlerio Vokietija pradžios. 